\title{
Experimental Optimization of Drilling Parameters in Tooling for Euro 7 Nozzle Production
}

\author{
Hakan Küçüktürk ${ }^{1 *}$, Gökhan Küçüktürk², Şükran Katmer ${ }^{3}$, Çağlar Yavaş ${ }^{4}$, Ulvi Şeker ${ }^{5}$ \\ 0000-0001-8200-6841, 0000-0002-2978-8968, 0000-0002-3641-2328, 0000-0002-2242-8425, 0000-0001-6455-6858 \\ ${ }^{1}$ Gazi University, Graduate School of Natural and Applied Sciences, Department of Manufacturing Engineering, 06500 Ankara/ Turkey \\ ${ }^{2}$ Gazi University, Faculty of Engineering, Department of Mechanical Engineering,06500 Ankara, Turkey \\ ${ }^{3}$ Gazi University, Graduate School of Natural and Applied Sciences, Mechanical Education, Teknikokullar 06500 Ankara/Turkey \\ ${ }^{4}$ Karcan Cutting Tools Industry and Trade Inc. 26110 Eskişehir/ Turkey \\ ${ }^{5}$ Gazi University, Faculty of Technology, Department of Manufacturing Engineering, 06500 Ankara/ Turkey
}

\section{Abstract}

Within the scope of Euro 7 emission norms, new types of injectors and engine parts are produced in order to reduce fuel consumption to minimum levels in diesel engine vehicles and accordingly to reduce emission rates. The complex geometry, high precision and high strength required by the nozzle design that will meet the requirements of the aforementioned norms have made the production of the required nozzles on existing production platforms difficult and the manufacturers have faced serious problems. Manufacturing companies needed the development of tooling systems suitable for the existing production platform rather than investing in the high-cost machine park. In this study, it is aimed to increase the tool life by choosing the most appropriate machining parameters for the surface quality obtained in the production of a single nozzle, which is designed and manufactured using six different tools, which will enable the use of existing machining platforms in the production of Euro 7 nozzles. The average surface roughness value on the nozzle surfaces was determined as $\mathrm{Ra}=0.34 \mu \mathrm{m}$ and it was observed that the desired surface quality was achieved. Performance tests have shown that the design and production activities are successful and that the developed tooling system can be used for the production of Euro 7 Nozzle from existing production platforms.

Keywords: Nozzle manufacturing, Drilling, Tooling, Force analysis

\section{Research Article}

https://doi.org/10.30939/ijastech..945993

\author{
Received 31.05.2021 \\ Revised 03.08.2021 \\ Accepted 16.08.2021
}

* Corresponding author

Hakan Küçüktürk

hakan.kucukturk@gazi.edu.tr

Address: Graduate School of Natural and Applied Sciences, Department of Manufacturing Engineering, 06500 Ankara/ Turkey

Tel:+ 903122028600

\section{Introduction}

It is known that new type injection nozzles are planned to be used in new-generation diesel engines. Although it is designed by giant companies in the sector, there are many problems in the prototype production of the nozzle. In order to reduce carbon emission rates in diesel engines, new types of injectors and diesel engine parts are developed by minimizing fuel consumption. In Euro 7 nozzles, it is necessary to produce 4 times higher surface quality than the previous Euro 6 type nozzles, more radial passages in the nozzle inner area for easier flow of fuel, and all these dimensions should also be produced with 4 times narrower tolerance and desired surface roughness values. Thus, the compression ratio, that is the pressure in the injectors and nozzles, can reach high levels. Thus, the compression ratio, that is the pressure in the injectors and nozzles, can reach high levels. High-strength materials that can serve in these conditions are needed. There is an increasing tendency to use $\mathrm{Cr}$ and $\mathrm{Ni}$ alloyed materials in recently developed products. Although this trend improves the high-pressure resistance of the parts and the friction-wear behavior under high pressure, it makes the machining of the part in the required high precision forms extremely difficult. Especially, it is expected that the production will be done economically with the optimum tool number and desired tolerances with conventional machines. Drilling is one of the main conventional machining methods used for many manufacturing areas [1]. Therefore, the development of tool design in this field and the theoretical and experimental study of machining parameters have an important place in the literature. In particular, theoretical studies on drilling have focused on the optimization of parameters by developing mathematical models for parameters that affect tool geometry and cutting forces, such as tool material, notch angle, drill diameter and coating [2-6]. Sambhav 
et al. presented a methodology for modeling the geometry of helical drills and drilling forces with the general tip geometry [7]. As a result of the experimental studies made after the changes made in the drill bit design especially for drilling highstrength steels, a decrease in cutting forces and moment has been observed and it is stated that tool breakage is reduced [8]. Gökçe et al. examined drill designs widely used in the industry and modeled a unique drill geometry based on parametric and mathematical equations for its manufacture [9]. Bahçe et al. [10] investigated the changes of burr heights in the hole exit area during the drilling of Al-5005 material. In the experimental studies, it was observed that different values of burr height were obtained while the drill bit geometries increase in the speed and feed rate. Yağmur et al. [11] drillability of AISI 1050 materials, widely used in industrial applications, examined the temperature alteration during metal removal based on hole type, cutting parameters, and cutting tool type. Uzun et al. [12] studied the drillability of Ti-6Al-4V alloys. They predicted that tool wear was the main reason for the change in cutting forces and hole quality as cutting speed and cutting time changed. Lin [13], stated that variable feed rate and variable rotational speed machining is an important method to improve cutting performance in hard and difficult to machine materials. Balaji et al. [14], studied the effect of cutting parameters such as cutting speed, feed rate and helix angle on tool life. The effects of cutting parameters were analyzed by evaluating the amplitude of drill bit vibration and surface roughness.

Austenitic stainless steels are widely used as engineering materials due their high strength, high corrosion and oxidation resistance properties and high chromium content as well as being used in the production of daily items. Although the quality of the holes in the drilling process depends on the machining parameters and the cutting tool and workpiece configurations, it is known that physical and metallurgical properties are important in the selection of machining parameters of AISI 304 austenitic stainless steels. Günay et al. studied on drilling of AISI 430 ferritic stainless steel in respect of the burr height, thrust force, and surface roughness by using Taguchi method combined with Grey Relational Grade (GRG). Furthermore, the mathematical models were developed for the machining outputs with response surface methodology [15]. Korkmaz et al. investigated the drilling process of AISI 420 martensitic stainless steel material in terms of feed force, moment, and tool temperature with the finite element method. And it was emphasized that the feed force and moment values increased as the feed rate increased, and these values tended to decrease with the increase in cutting speed [16].

Chatterjee et al. investigated the effect of drilling parameters, spindle rotation speed, feed rate and drill bit diameter on burr height and the hole quality in drilling AISI 304 austenitic stainless steels using a parametric evaluation [17]. It is emphasized in some studies that multi-layer coatings applied on cutting tools have an effect on cutting forces and hole diameter in the drilling of AISI 304 austenitic stainless steel [18, 19]. Nanocomposite coated and uncoated tungsten carbide tools were examined in terms of surface roughness and tool wear when drilling AISI-
304L austenitic stainless steel workpieces, and it was stated that less damage occurred in coated tools [20]. During dry drilling operations, it is known that coated tools are more successful in reducing tool wear and improving the surface roughness of the workpiece, depending on parameter changes such as cutting speed and feed rate [21, 22]. Given the effect of cutting parameters on surface roughness and chip formation during drilling of Inconel718 superalloy with coated and uncoated carbide drills, the best results in terms of surface roughness were obtained with holes drilled with an uncoated tool [23].

As a result of the literature review, the researchers generally conducted studies on the drilling of austenitic stainless steels with drilling bits with different material structures and coated with different materials. It has been determined that in particular to AISI 304 austenitic stainless steel, studies have been carried out to prevent tool wear encountered during machining, to increase hole quality, to determine optimum machining parameters and to compare them with existing tools. These studies focused on the values that affect the hole quality such as surface roughness, burr height, and conic hole formation. They also focused on machining parameters such as cutting speed, feed rate, rotation speed, and tool properties such as the drill tip angle and the tool material and type of coatings. Although there are studies in the literature on drilling holes in AISI 304 austenitic stainless steel, there is a deficiency for studies to determine the production process of Euro 7 nozzle holes. Within this scope, there is a need for studies to determine the issues to be considered in the design of the tool geometry and to develop different tool geometries. Surface roughness is an indicator of surface quality, which is the main requirement of the automotive parts that need precise production such as nozzles. Since the compression ratio, so the service pressure, in injectors and nozzles will be at high levels, the surface roughness will be one of the most important parameters that directly affect the friction coefficient and the flow quality. Proper tool design and parameter selection become an important issue in the production of Euro 7 type nozzles in order to obtain proper nozzle surface roughness, which is an important factor in reducing emission values. In this study, it is aimed to increase the tool life by choosing the most suitable machining parameters for the surface quality of many nozzles produced using six different tools.

\section{Experimental Study:}

Pilot tests of prototype tools were carried out with a vertical machining center (ARION IMM-1100 Vertical Machining Center) with a maximum spindle speed of $8000 \mathrm{rpm}$ and a drive motor of 11/7.5 kW (Fig. 1). Chemical properties for AISI 304 austenitic stainless steel material are given in Table 1. 
Table 1. Chemical composition of AISI 304 austenitic stainless steel [24]

\begin{tabular}{c|c}
\hline Element & Composition (\%wt.). \\
\hline $\mathrm{C}$ & 0.059 \\
\hline $\mathrm{Si}$ & 0.581 \\
\hline $\mathrm{Mn}$ & 1.080 \\
\hline $\mathrm{P}$ & 0.029 \\
\hline $\mathrm{S}$ & 0.001 \\
\hline $\mathrm{Cr}$ & 18.060 \\
\hline $\mathrm{Ni}$ & 8.150 \\
\hline $\mathrm{Mo}$ & 0.064 \\
\hline $\mathrm{Cu}$ & 0.150 \\
\hline $\mathrm{Fe}$ & Balance \\
\hline
\end{tabular}

Experimental studies were prepared by cutting 80x80x40 mm blocks in order to perform serial processing. On each block, it is aimed to drill numbers of 25 and 50 Euro7 diesel injector nozzle geometries serially with 6 tools, so as considering not to be affected by the thermal changes that will occur during machining. After the tool designs and analyzes of the drilling bits used in the experiments were made, they were produced in Karcan Cutting Tools Industry and Trade Inc. (Fig. 2). Surface control has achieved by milling the hole entry surfaces of the target material and controlling the radial runout of the tools. All experiments were carried out in wet conditions, similar to the applications in the field, and boron oil emulsion with $6 \%$ concentration was used as cutting fluid. The tool runout measurements and bench setup processes of the drill bits were completed and machining experiments were carried out within the framework of the usage order of the tools with the generated CAM program (Fig. 3).

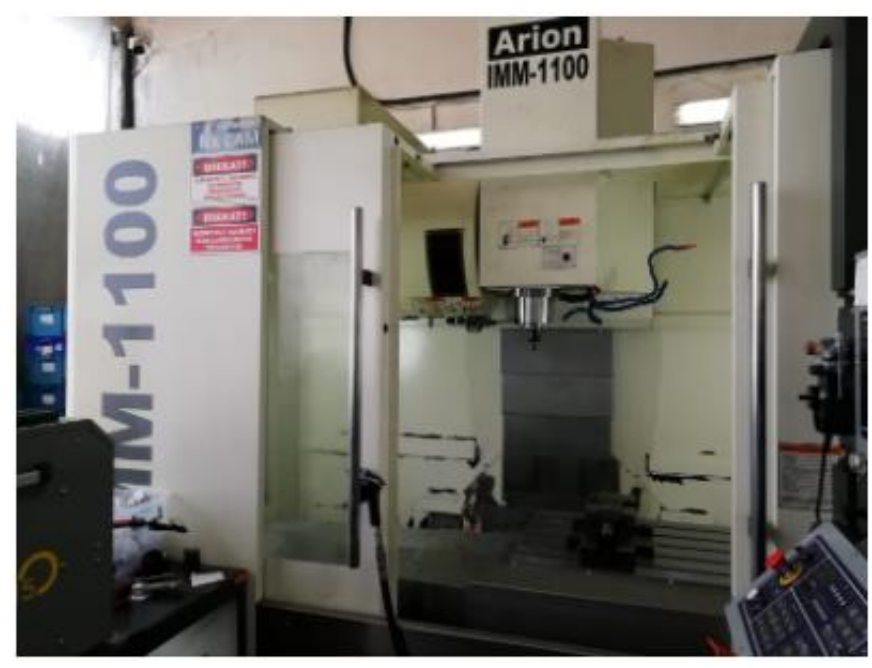

Fig. 1. CNC Vertical Machining Center used for experimental studies

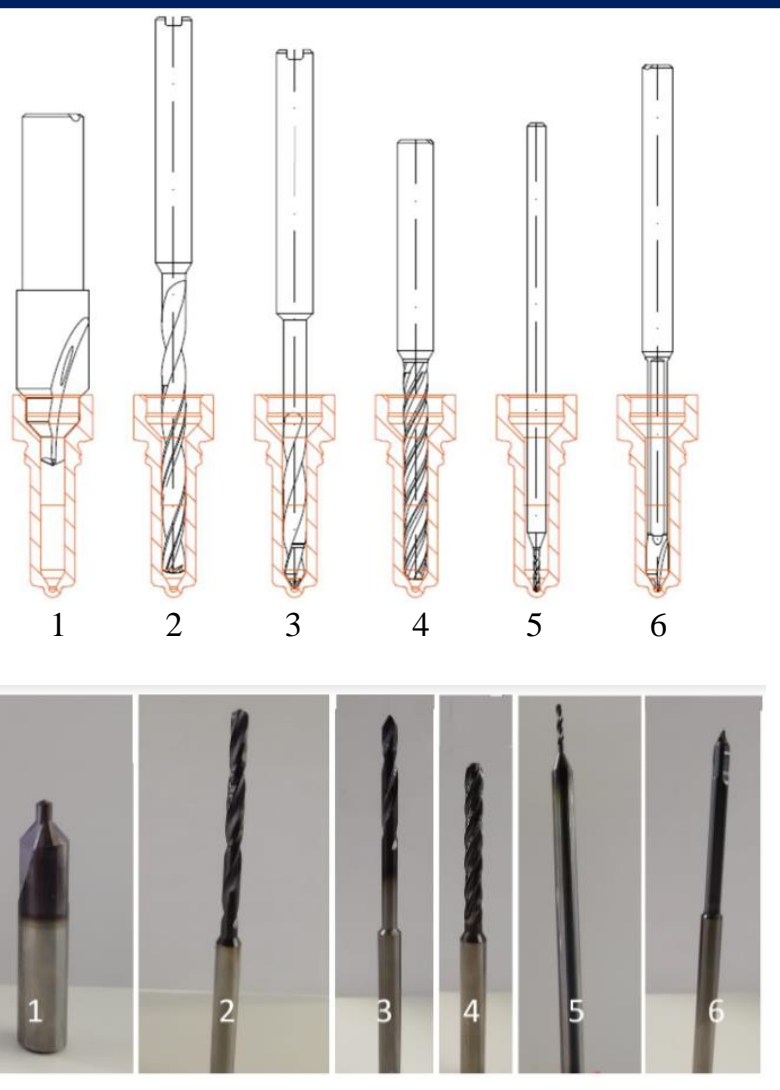

Fig. 2. Tooling system developed for Euro7 Nozzle and tools [24]
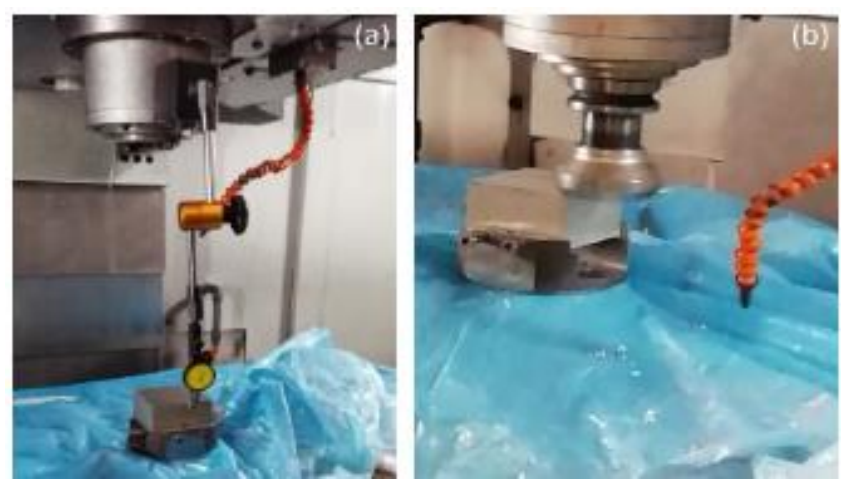

Fig. 3. (a) tool run-out control attached to the spindle; and (b) workpiece surface cleaning

\section{Evaluation of Drilling Performance}

\subsection{The determination of appropriate drilling parameters}

Four types of parameter groups have been determined for the experimental optimization of drilling parameters. The parameters and success conditions determined for six tools and the machining parameters determined for life determination are presented in Table 2. It was observed whether the nozzle structure for 49 nozzle holes was successfully drilled by using the planned parameter sets on the target material (Fig. 4). 


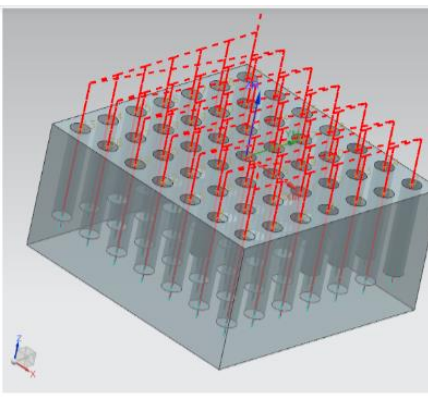

(a)

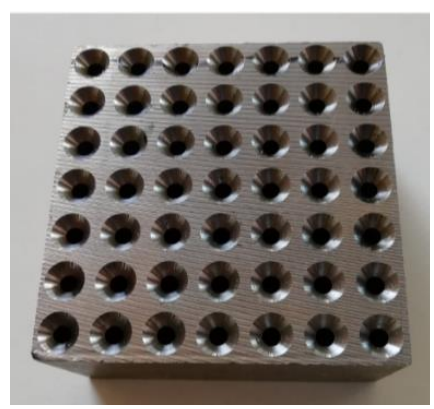

(b)
Fig. 4. (a) Hole design and (b) final nozzles on block work pieces

It was carried out by measuring the hole inlet and bottom diameters on the test samples and these diameters were verified. In order to verify the nozzle geometries and surface quality obtained in the drilling tests, the samples were cut using a wire electro erosion machine based on the hole axis (Fig. 5). Average surface roughness measurements were made on the nozzle surfaces after cutting and $R_{a}$ values were determined.

When the revolution speed is increased, the amount of flank wear on the tools increased excessively and this caused the tools to have a shorter life. Fig. 6 shows the change in tool according to the specified parameter sets. The increase in speed caused an increase in surface roughness values for 49 holes on the target part.

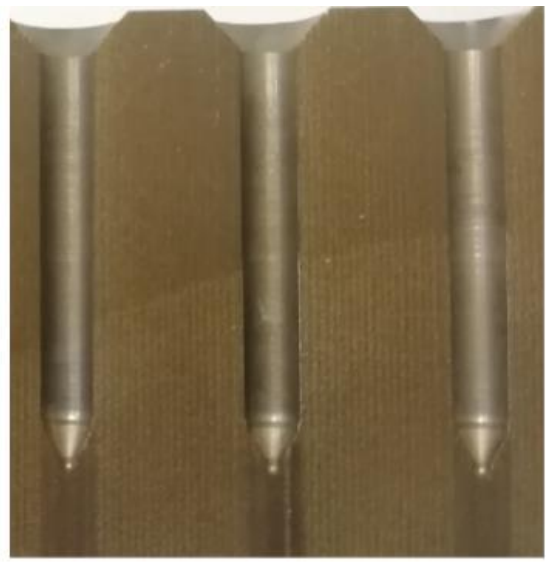

Fig. 5. The view of nozzles after cutting with wire electro erosion

In order to achieve tool life targets, FW results were obtained much lower than the accepted $(<0.06 \mathrm{~mm})$ values (Fig. 7). In the study performed with four different parameter sets in the drilling process with Tool 1, the best flank wear value of $0.003 \mathrm{~mm}$ was obtained with $1500 \mathrm{rpm}$ and $0.02 \mathrm{~mm} /$ tooth. The flank wear values were found to be $0.015 \mathrm{~mm}, 0.027 \mathrm{~mm}$ and $0.042 \mathrm{~mm}$, respectively, when the feed rate was kept constant and the revolution speeds were $3000 \mathrm{rpm}, 4000 \mathrm{rpm}$ and $6000 \mathrm{rpm}$.

It is aimed to find the optimum values as a result of processing in two steps with Tool 2. Successful holes were drilled with 0.02 $\mathrm{mm} /$ tooth and $0.015 \mathrm{~mm} /$ tooth parameters at $2800 \mathrm{rpm}$, and these values were accepted as optimum values since the best flank wear result obtained in terms of flank wear was $0.009 \mathrm{~mm}$.
Since the surface roughness values are too high in other machining parameters, they are not shown in the chart.

Tool flank wear was measured as $0.004 \mathrm{~mm}$ as a result of machining parameter values for Tool 3, which was performed in two operations, at $2800 \mathrm{rpm}$ and $0.01 \mathrm{~mm} /$ tooth in the first operation, and $0.02 \mathrm{~mm} /$ tooth at $2800 \mathrm{rpm}$ in the second operation. Similarly, other parameter values were not accepted. As a result of a single operation, machining with Tool 4 was carried out in four different machining parameters. Accepted flank wear values of $0.005 \mathrm{~mm}, 0.027 \mathrm{~mm}$ and $0.060 \mathrm{~mm}$ are respectively revolution speed and feed rate $6000 \mathrm{rpm}$ for $0.05 \mathrm{~mm} /$ tooth, measured for $6000 \mathrm{rpm}$ for $0.0625 \mathrm{~mm} /$ tooth and $7000 \mathrm{rpm}$ for 0.0625 $\mathrm{mm} /$ tooth. Because the flank wear values were too high, 8000 $\mathrm{rpm}$ for $0.0625 \mathrm{~mm} /$ tooth was not taken into account.

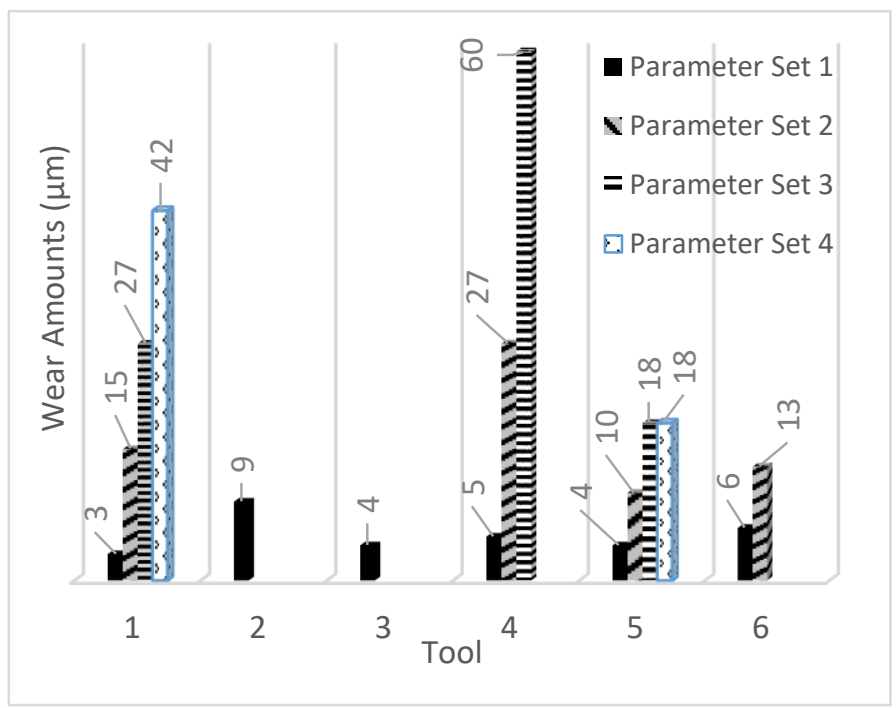

Fig. 6. The view Change in tool wear due to cutting speed after fifty holes

In drilling trials with Tool 5, the flank wear results of four different rotational speeds increasing with a single 0.015 $\mathrm{mm} /$ tooth feed value were measured as $0.004 \mathrm{~mm}, 0.01 \mathrm{~mm}$, $0.018 \mathrm{~mm}$ and $0.018 \mathrm{~mm}$, respectively. The best parameter value was obtained as a result of $4500 \mathrm{rpm}$ and $0.015 \mathrm{~mm} /$ tooth parameter. Machining was carried out with tool 6 at $0.01 \mathrm{~mm} /$ tooth feed rate and four different rotational speeds. Since the flank wear results for $6000 \mathrm{rpm}$ and $8000 \mathrm{rpm}$ are relatively high, only the $0.006 \mathrm{~mm}$ and $0.013 \mathrm{~mm}$ flank wear values obtained at 3000 rpm and $4500 \mathrm{rpm}$ are taken into account. As a result, it was decided that the best parameter set is suitable as $0.001 \mathrm{~mm} /$ tooth feed for $3000 \mathrm{rpm}$.

The nozzle inner average surface roughness values obtained with the most suitable parameter sets are presented in Fig. 7. As a result of the studies carried out with Parameter Set 1 (PS1), the best tool flank wear amount was obtained, and the lowest internal surface roughness values were also obtained with this set. Although the surface roughness after machining with Parameter Set 2 (PS2) and Parameter Set 3 (PS3) were at acceptable values, studies were continued with the parameters in which the best 
tool flank wear was obtained (Table 3).

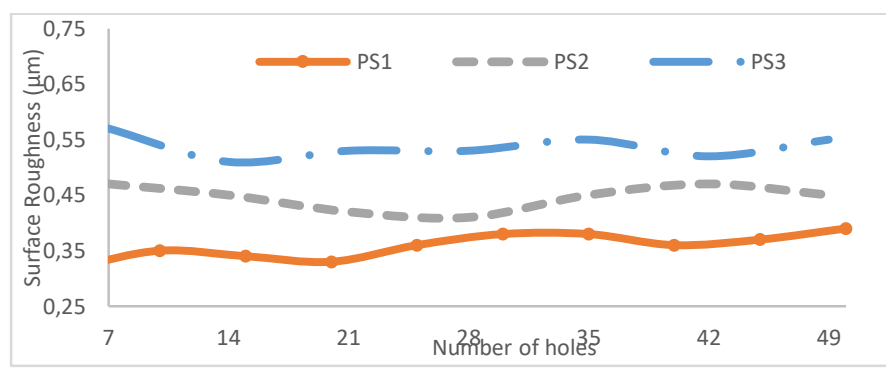

Fig. 7. Change in surface roughness in specified parameter sets

Table 2. Parameter sets

\begin{tabular}{|c|c|c|c|c|c|c|c|c|}
\hline & $\begin{array}{c}\text { Speed } \\
\text { [rpm] } \\
\text { (1st } \\
\text { operation) } \\
\end{array}$ & $\begin{array}{c}\text { Feed } \\
\text { rate } \\
{[\mathrm{mm} /} \\
\text { tooth] }\end{array}$ & Result & $\begin{array}{l}\text { Operation } \\
\text { notes }\end{array}$ & $\begin{array}{l}\text { Speed } \\
\text { [rpm] } \\
\text { (2nd } \\
\text { operation) }\end{array}$ & $\begin{array}{c}\text { Feed } \\
\text { rate } \\
{[\mathrm{mm} /} \\
\text { tooth] }\end{array}$ & Result & $\begin{array}{c}\text { Operation } \\
\text { notes }\end{array}$ \\
\hline $\begin{array}{l}\text { TOOL } 1 \\
\text { (single } \\
\text { operation) }\end{array}$ & 1500 & 0.02 & successful & \multirow{4}{*}{-} & - & - & - & 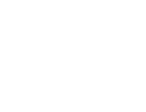 \\
\hline \multirow{3}{*}{$\begin{array}{c}\text { TOOL 1 } \\
\text { (two } \\
\text { operation) }\end{array}$} & 3000 & \multirow{3}{*}{0.02} & \multirow{3}{*}{ successful } & & 1500 & \multirow{3}{*}{0.02} & \multirow{3}{*}{ successful } & - \\
\hline & 4000 & & & & 2000 & & & \\
\hline & 6000 & & & & 3000 & & & \\
\hline \multirow{4}{*}{$\begin{array}{c}\text { TOOL } 2 \\
\text { (two } \\
\text { operation) }\end{array}$} & 2800 & \multirow{4}{*}{0.02} & \multirow[b]{2}{*}{ successful } & \multirow{4}{*}{$\begin{array}{l}3 \mathrm{~mm} \\
\text { pecking }\end{array}$} & 2800 & 0.015 & successful & \multirow{4}{*}{$\begin{array}{l}3 \mathrm{~mm} \\
\text { pecking }\end{array}$} \\
\hline & 2800 & & & & 2800 & \multirow{3}{*}{0.03} & \multirow{3}{*}{ unsuccessful } & \\
\hline & 4000 & & \multirow{2}{*}{ unsuccessful } & & 4000 & & & \\
\hline & 6000 & & & & 6000 & & & \\
\hline \multirow{5}{*}{$\begin{array}{c}\text { TOOL } 3 \\
\text { (two } \\
\text { operation) }\end{array}$} & & \multirow{5}{*}{0.01} & & \multirow{5}{*}{$\begin{array}{c}0.7 \mathrm{~mm} \\
\text { pecking }\end{array}$} & & & & \\
\hline & 2800 & & \multirow{2}{*}{ successful } & & 2800 & 0.01 & successful & \multirow{4}{*}{$\begin{array}{l}0.4 \mathrm{~mm} \\
\text { final pass }\end{array}$} \\
\hline & 2800 & & & & 2800 & \multirow{3}{*}{0.02} & \multirow{3}{*}{ unsuccessful } & \\
\hline & 4000 & & \multirow{2}{*}{ unsuccessful } & & 4000 & & & \\
\hline & 6000 & & & & 6000 & & & \\
\hline \multirow{5}{*}{$\begin{array}{c}\text { TOOL } 4 \\
\text { (two } \\
\text { operation) }\end{array}$} & & & \multirow{4}{*}{ successful } & \multirow{5}{*}{-} & \multirow{5}{*}{ - } & \multirow{5}{*}{ - } & \multirow{5}{*}{-} & \\
\hline & 6000 & 0.05 & & & & & & \multirow{4}{*}{ - } \\
\hline & 6000 & \multirow{3}{*}{0.0625} & & & & & & \\
\hline & 7000 & & & & & & & \\
\hline & 8000 & & unsuccessful & & & & & \\
\hline \multirow{4}{*}{$\begin{array}{c}\text { TOOL } 5 \\
\text { (two } \\
\text { operation) }\end{array}$} & 4500 & & & & & & & \\
\hline & $\begin{array}{l}4500 \\
6000\end{array}$ & & & $0.5 \mathrm{~mm}$ & & & & \\
\hline & 7000 & 0.015 & successful & pecking & - & - & - & \\
\hline & 8000 & & & & & & & \\
\hline & & & & & & & & \\
\hline & 3000 & & & & & & & \\
\hline TOOL 6 & 4500 & 001 & successiul & 0.1 s stand & - & & & \\
\hline operation) & 6000 & 0.01 & unsuccessful & bottom & - & & - & - \\
\hline & 8000 & & 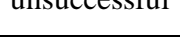 & & & & & \\
\hline
\end{tabular}


Table 3. Recommended drilling parameters for tool life estimation

\begin{tabular}{l|c|c|c}
\hline \multirow{2}{*}{ Tool } & $\begin{array}{c}\text { Speed } \\
{[\mathrm{rpm}]}\end{array}$ & $\begin{array}{c}\text { Feed rate } \\
{[\mathrm{mm} / \text { tooth }]}\end{array}$ & Operation notes \\
\hline 1st tool & 1500 & 0.020 & \\
\hline \multirow{2}{*}{ 2nd tool } & 2800 & 0.020 & $3 \mathrm{~mm}$ pecking \\
\cline { 2 - 3 } 3rd tool & 2800 & 0.015 & $0.7 \mathrm{~mm}$ pecking \\
\hline 4th tool & 2800 & 0.010 & $0.4 \mathrm{~mm}$ final pass \\
\hline 5th tool & 4500 & 0.050 & $0.5 \mathrm{~mm}$ pecking \\
\hline 6th tool & 3000 & 0.015 & $0.1 \mathrm{~s} \mathrm{stand} \mathrm{at} \mathrm{the} \mathrm{bottom}$ \\
\hline
\end{tabular}

\subsection{Performance tests}

AISI 304 austenitic stainless steel material with the same chemical composition as the target material has been used for the pilot performance tests of the prototype cutting tools. In order to perform serial processing in performance tests and to be suitable for the dynamometer used in force/moment measurements, test samples were prepared by cutting 80x80x40 mm block sizes. It aimed that 25 Euro 7 diesel injector nozzle geometry were drilled serially with 6 different tools in each block at a distance that would not be affected by the thermal changes that occur during machining. As can be seen in Fig. 8, numbers of 25 nozzles have successfully drilled.

Kistler type 9272 dynamometer and Kistler type 5070 amplifier operating on the basis of quartz crystal, capable of measuring three shear force components $\left(F_{x}, F_{y}, F_{z}\right)$ and moment $\left(M_{z}\right)$ simultaneously, were used in the experimental determination of shear forces and moments.

Experiments were carried out in order to determine the performance indicators of each tool with the machining parameters accepted as suitable, with tool flank wear and nozzle surface roughness values. During the experiments, shear forces (Fx, Fy, and $\mathrm{Fz}$ ) and moment $(\mathrm{Mz})$ values were measured and recorded for each

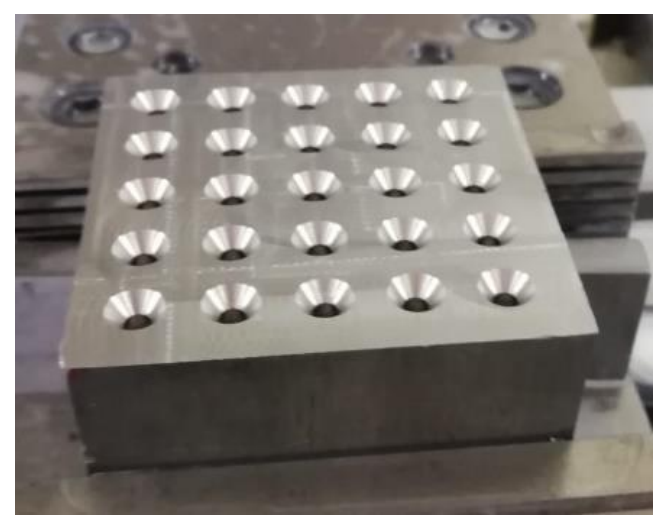

Fig. 8. Holes drilled with performance tests operation and each nozzle hole. Average force and moment values were measured from the graphs evaluated with Kistler Dynaware software. The performance tests of the tools were repeated, and numbers of 25 Euro 7 nozzle geometries were obtained by working successively on each sample. Apart from pecking recommended for tools with high chip load, drilling operations were found suitable to be completed in two stages as in field applications. All drilling tests after the Design/Production validation activities have carried out using the same device and hardware as in the first pilot trials. The only difference is that the dynamometer is attached to the bench vise instead of directly to the benchtop. Thus, the preloads in the Fz direction are reduced.

For tool 1, it was observed that the values of $\mathrm{Fz}=239.80 \mathrm{~N}$ and $M z=263 \mathrm{~N} . \mathrm{cm}$ increased due to the increased number of holes as a result of serial processing of the nozzles in a single operation (Fig. 9).

It has been observed that the $\mathrm{Fz}$ and $\mathrm{Mz}$ values for tool 2, which was processed in two different stages, increased with the number of holes. These values were measured as maximum $\mathrm{Fz}=33.6 \mathrm{~N}$ and $\mathrm{Mz}=248 \mathrm{~N} . \mathrm{cm}$ in the first stage, and as $\mathrm{Fz}=55.42$ $\mathrm{N}$ and $\mathrm{Mz}=234.6 \mathrm{Ncm}$ in the second stage. Considering the nozzle and tool geometry the reason for the significant decrease in the thrust force while compared to the machining values of the first tool is understood (Fig. 10).

The highest values were measured as $\mathrm{Fz}=36.65 \mathrm{~N}$ and $\mathrm{Mz}=121 \mathrm{~N} . \mathrm{cm}$ in the first step, and as $\mathrm{Fz}=34.78 \mathrm{~N}$ and $\mathrm{Mz}=265$ N.cm in the second step in the drillings where tool 3 was used. As a result of all drillings, the average drilling force values were measured as $34.25 \mathrm{~N}$ and $103.84 \mathrm{~N} . \mathrm{cm}$ in the first stage and $30.69 \mathrm{~N}$ and $258.80 \mathrm{~N} . \mathrm{cm}$ in the second stage. Some fluctuations in forces have been attributed to the material's nickel content which is resulting in a tendency for the chip to become entangled in the tool and to re-cut (Fig. 11). 


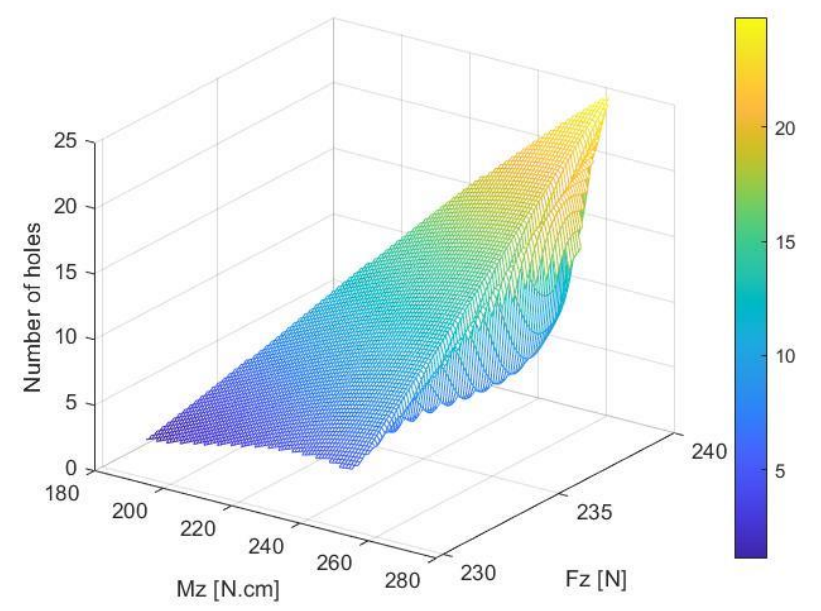

Fig. 9. Variation in torque and thrust forces for tool 1 depending on the number of holes

As a result of machining using Tool 4, a change as in Fig. 12 was obtained. The highest $\mathrm{Fz}$ and $\mathrm{Mz}$ values, obtained as a result of machining all holes in a single operation, were $68.42 \mathrm{~N}$ and $121 \mathrm{~N} . \mathrm{cm}$, respectively, while the average values were $68.36 \mathrm{~N}$ and 118 N.cm. It was interpreted that the increase in $\mathrm{Fz}$ force compared to the previous tooling increased with the diameter expansion in the nozzle, and similarly, the decrease in $\mathrm{Mz}$ moment was due to the decrease in the forces in the Fx and Fy directions resulting from the diameter expansion.

In the drillings where tool 5 was used, the highest values were measured as $\mathrm{Fz}=39.46 \mathrm{~N}$ and $\mathrm{Mz}=44 \mathrm{~N} . \mathrm{cm}$ in the first stage, and as $\mathrm{Fz}=34.58 \mathrm{~N}$ and $\mathrm{Mz}=23 \mathrm{~N} . \mathrm{cm}$ in the second stage. As a result of all drillings, the average hole drilling values were measured as $34.04 \mathrm{~N}$ and $36.33 \mathrm{Ncm}$ in the first stage and $33.13 \mathrm{~N}$ and 19.67 N.cm in the second stage (Fig. 13).

Nozzle geometry is finalized after machining with the last tool in a single operation. The highest $\mathrm{Fz}$ and $\mathrm{Mz}$ values were determined as $40.76 \mathrm{~N}$ and $272 \mathrm{~N} . \mathrm{cm}$, respectively, while the average values were determined as $34.66 \mathrm{~N}$ and $209.13 \mathrm{~N} . \mathrm{cm}$.

Depending on the increase in the number of holes, an increasing trend in the Fz force, in general, is observed when the graphics are examined. However, this increasing trend did not reach a level that would negatively affect tool performance (Fig. 14).

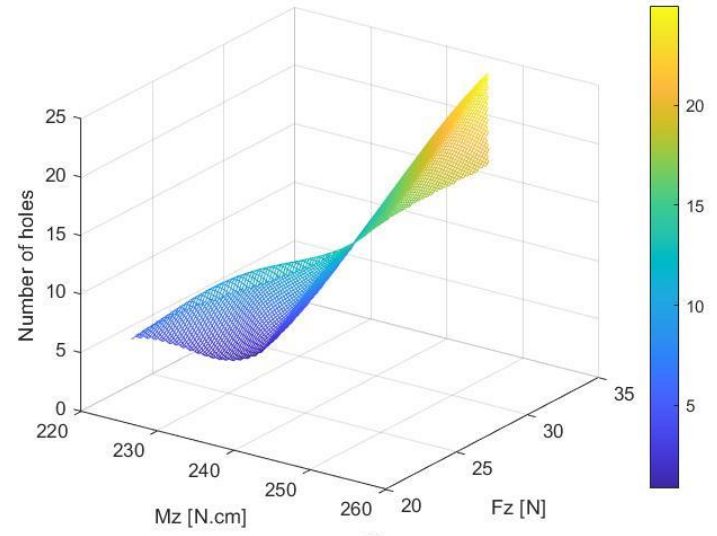

(a)

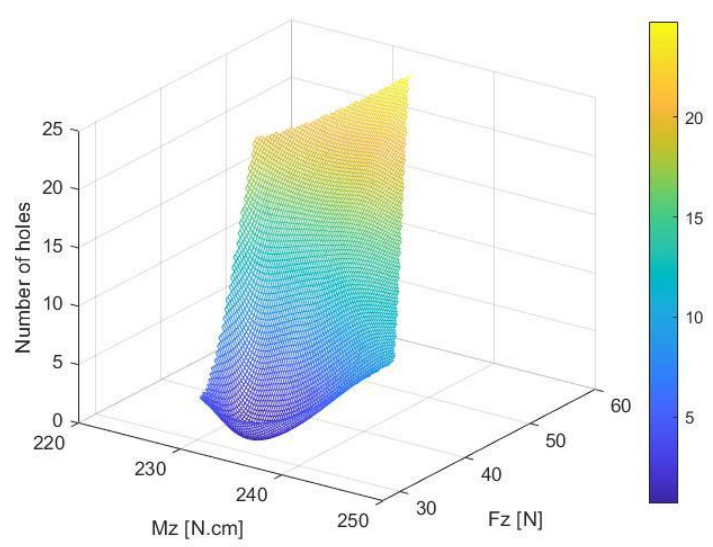

(b)

Fig. 10. (a) Change in torque and thrust forces depending on the number of holes in the 1st stage for Tool 2 (b) Change in torque and thrust forces depending on the number of holes in the 2nd stage for Tool 2 


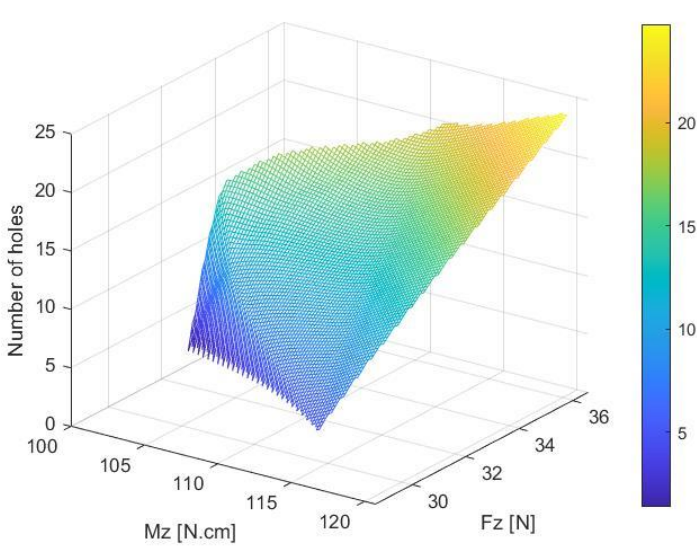

(a)

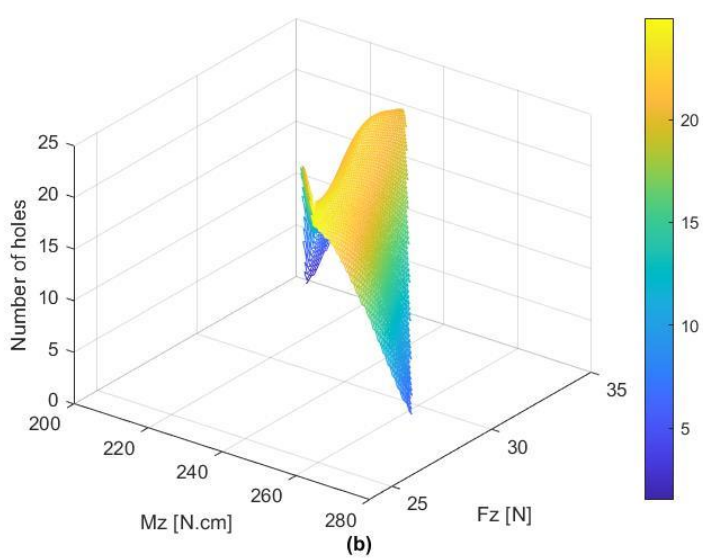

Fig. 11. (a) Change in torque and thrust forces depending on the number of holes in the 1st stage for Tool 3 (b) Change in torque and thrust forces depending on the number of holes in the 2nd stage for Tool 3

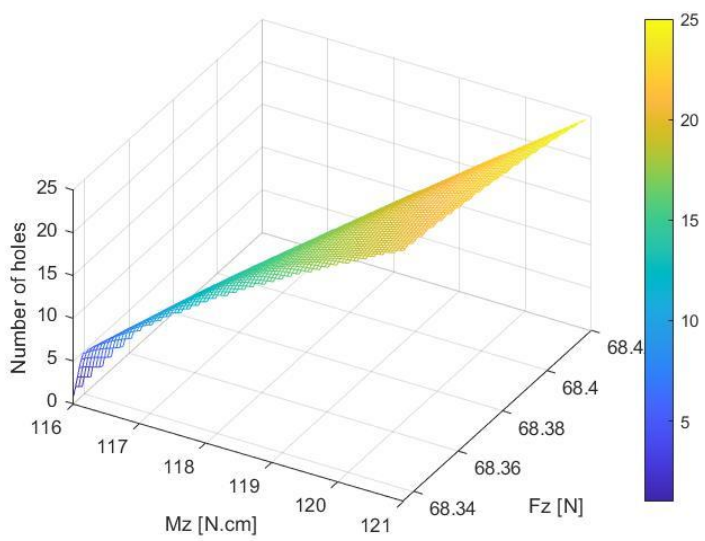

Fig. 12. Variation in torque and thrust forces for tool 4 depending on the number of holes

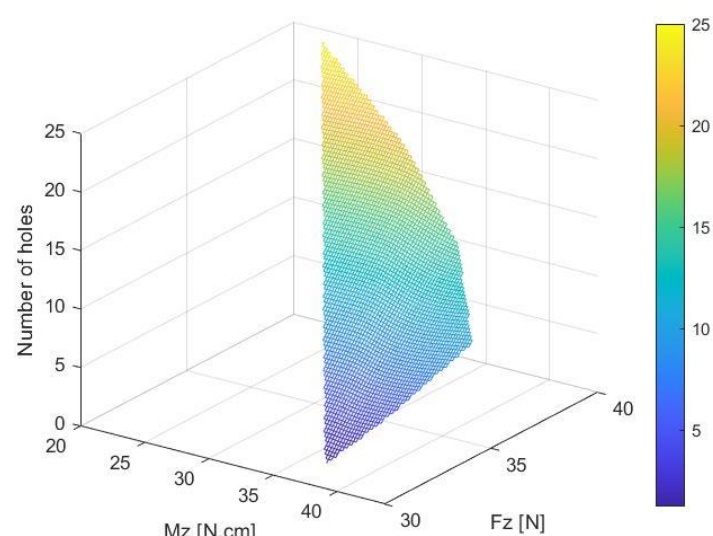

(a)

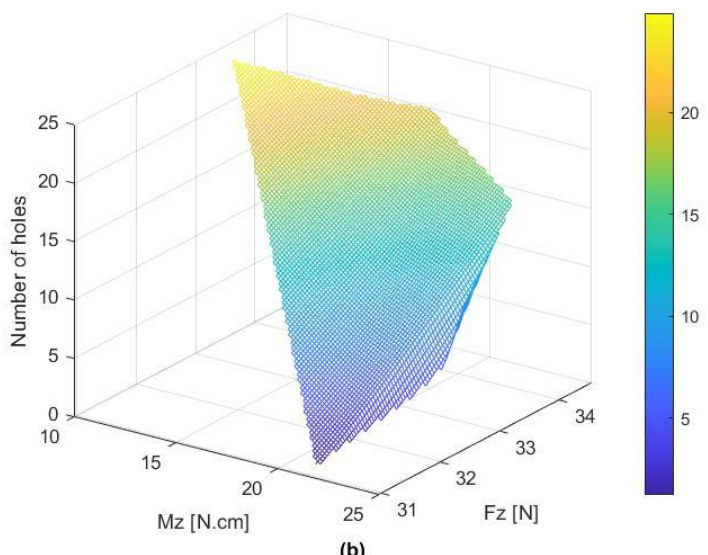

Fig. 13. (a) Change in torque and thrust forces depending on the number of holes in the 1st stage for Tool 3 (b) Change in torque and thrust forces depending on the number of holes in the 2nd stage for Tool 5

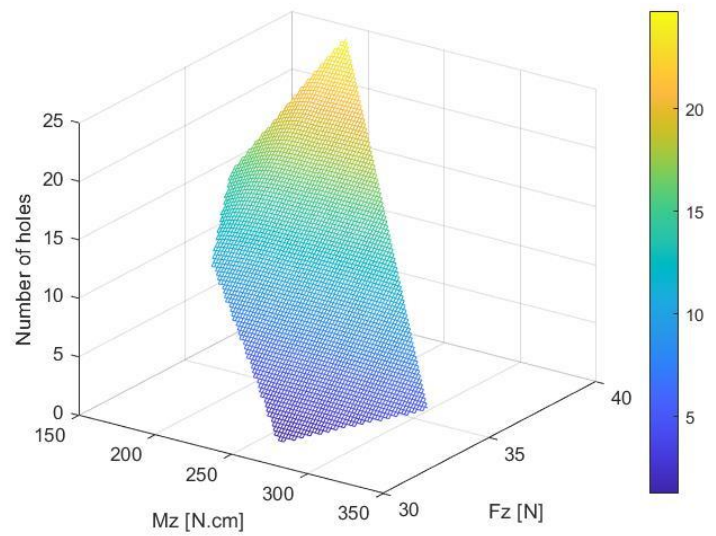

Fig. 14. Variation in torque and thrust forces for tool 4 depending on the number of holes 
This shows that the design and production activities are successful. The most stable data in terms of thrust force $(\mathrm{Fz})$ were observed in the number 4 tool, the reaming tool. This has been attributed to the low depth of cut left to the reaming tools, as the nature of the reaming process. When the moment $(\mathrm{Mz})$ graphs were evaluated, it has seen that the general trend was parallel to the trend in the Fz force. Since the torsional moment values have affected by the Fx and Fy forces depending on the chip load of each tool, they spread over a wider range and tended to increase slightly in parallel with the increase in the number of holes.

\section{Tool Life}

After parameter determination and performance tests, a total of 295 nozzles have machined with each tool one after the other. With the help of the curves in the graph given in Fig. 15, it was understood that the flank wear values were at reasonable levels $(\leq 0.06 \mathrm{~mm})$ and the tool life values determined for the tools can be reached.

In addition, the measured surface roughness values of the nozzle inner surface made measurable by the wire electro-erosion method are shown in Fig. 16. In the study, it has seen that the roughness values of the nozzle surface obtained after drilling 295 holes were at an acceptable level.

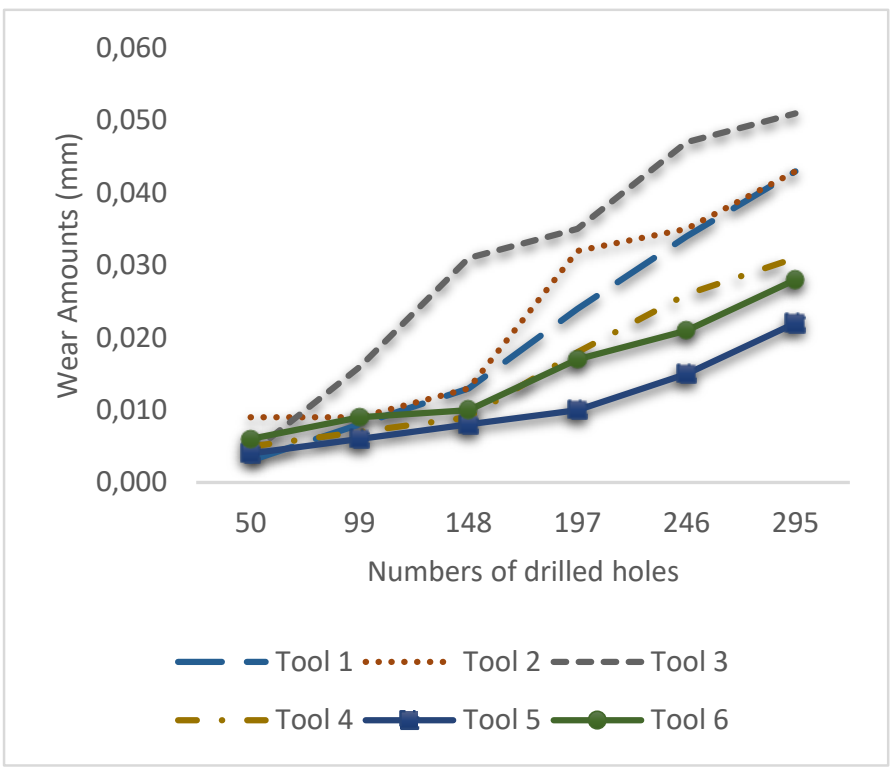

Fig. 15. Change in tool flank wear depending on the number of holes in tool life tests

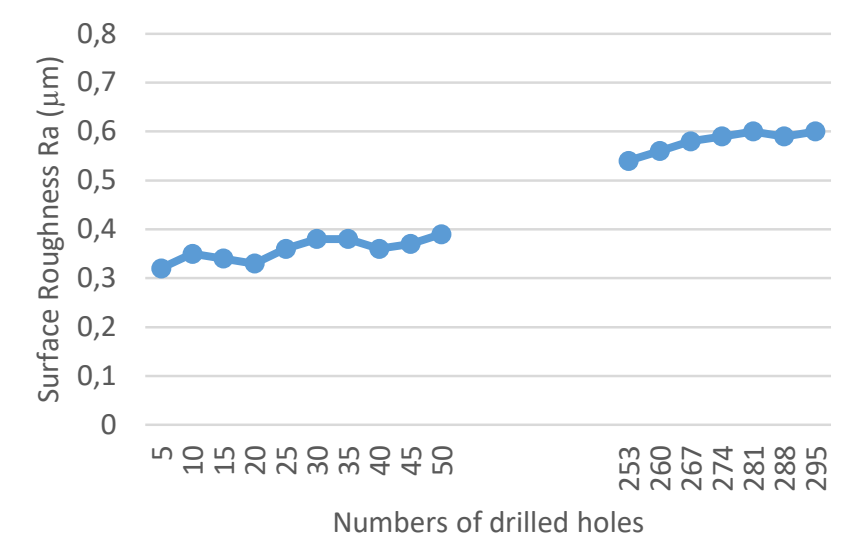

Fig. 16. Change in nozzle surface roughness depending on the number of holes in tool life tests

\subsection{Modelling}

A linear model was applied for surface roughness and tool flank wear values by the graphical simulation method. A mathematical model was generated using the graphical simulation method for the tool flank wear values shown in Table 4. Linear graphs have drawn using the linear simulation method, using the flank wear values that change depending on the number of holes in each tool, as shown in Fig. 17.

Table 4. Tool flank wear amounts according to the number of holes

\begin{tabular}{|c|c|c|c|c|c|c|}
\hline Number of Holes & Tool 1 & Tool 2 & Tool 3 & Tool 4 & Tool 5 & Tool 6 \\
\hline 50 & 0.003 & 0.009 & 0.004 & 0.005 & 0.004 & 0.006 \\
\hline 99 & 0.008 & 0.009 & 0.016 & 0.007 & 0.006 & 0.009 \\
\hline 148 & 0.013 & 0.013 & 0.031 & 0.009 & 0.008 & 0.010 \\
\hline 197 & 0.024 & 0.032 & 0.035 & 0.018 & 0.010 & 0.017 \\
\hline 246 & 0.034 & 0.035 & 0.047 & 0.026 & 0.015 & 0.021 \\
\hline 295 & 0.043 & 0.043 & 0.051 & 0.031 & 0.022 & 0.028 \\
\hline
\end{tabular}




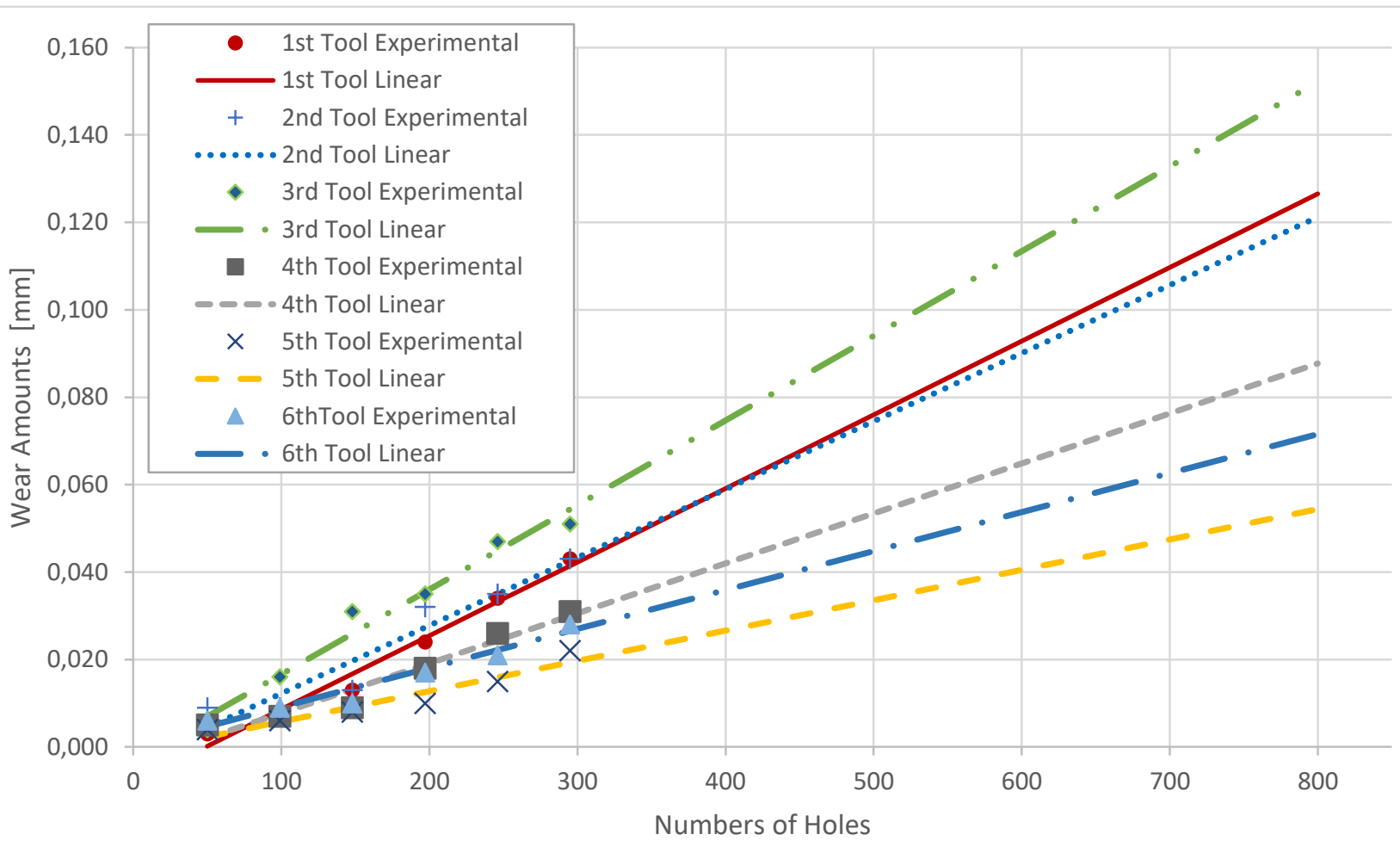

Fig. 17. Experimentally and theoretically the change in tool wear depending on the number of holes of the tools

Table 5. $\mathrm{R}^{2}$ values calculated for each tool

\begin{tabular}{c|c}
\hline & $\mathrm{R}^{2}$ \\
\hline Tool 1 & 0.978 \\
\hline Tool 2 & 0.913 \\
\hline Tool 3 & 0.969 \\
\hline Tool 4 & 0.946 \\
\hline Tool 5 & 0.916 \\
\hline Tool 6 & 0.953 \\
\hline
\end{tabular}

When these values were examined, it has seen that the model is matching with over $90 \%$ accuracy for each cutting tool.

Using these data, the coefficients of determination $\left(\mathrm{R}^{2}\right)$ values given in Table 5 have calculated. Generated mathematical models for each tool flank wear are presented below:

Wear amount of Tool $1=-0.00824+0.000168513 \times$ Number of Holes

Wear amount of Tool 2. $=-0.00336+0.000155685 \times$ Number of Holes
Wear amount of Tool 3. $=-0.00273+0.000193586 \times$ Number of Holes

Wear amount of Tool 4. $=-0.00371+0.000114286 \times$ Number of Holes

Wear amount of Tool 5. $=-0.00114+0.0000693878 \times$ Number of Holes

Wear amount of Tool 6. $=0.000222546+0.0000892128 \times$ Number of Holes

Another output of the experimental studies was the surface roughness. The graph of the model showing the average surface roughness values depending on the number of holes is shown in Fig. 18. It has been observed that the determination coefficient $\mathrm{R} 2$ value calculated by following the steps in the same direction as the models generated for tool flank wear was very close to 1 . Generated mathematical mode emerged as:

$\mathrm{Ra}=0.33256+0.00090584 \times$ Number of Holes

In addition, studies continue on models based on the obtained parameter sets in order to determine the most appropriate parameter values. 


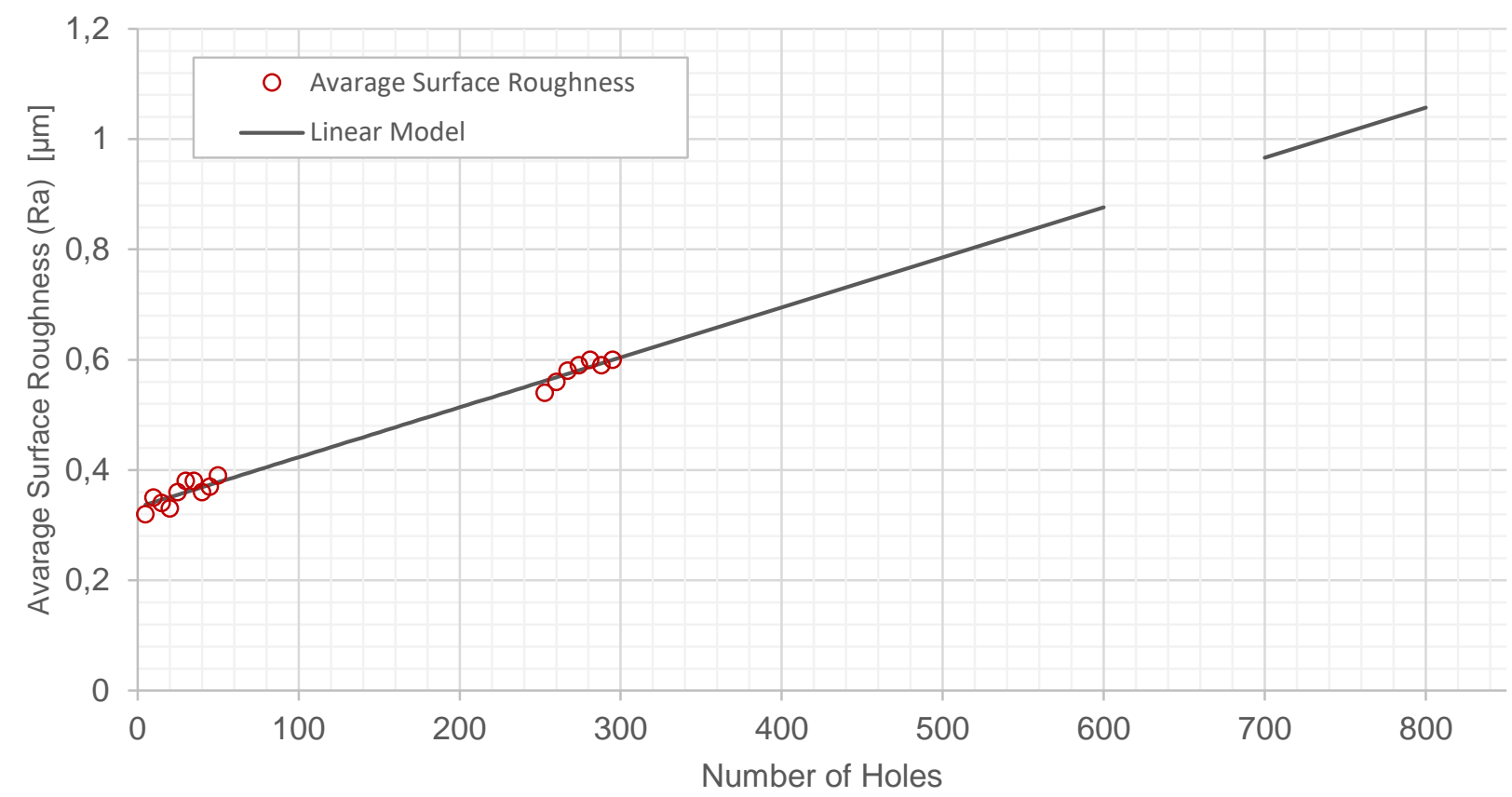

Fig. 18. Change in surface roughness depending on the number of holes

\section{Conclusions}

As a result, experimental studies were performed to determine the issues that need to be evaluated in the tool design to be used in drilling holes during the production of Euro7 nozzles and to develop different tool geometries. In serial nozzle hole drilling processes using cutting tools with six different geometries, a large number of drilling operations have carried out depending on the surface roughness, various cutting speeds and feed rates. The main contribution of the study is to find optimum drilling conditions suitable for minimum surface roughness and tool flank wear by drilling many holes with the same drills. Modeling and optimization studies have shown that the number of experimental studies can be reduced and provided a systematic and effective methodology. The estimated and measured values from the modeling results have found quite close. This showed that the developed model could be used effectively to predict surface roughness and tool flank wear. A significant saving in time and cost has been achieved by using this model.

In the performance tests, depending on the increase in the number of holes, there was an increase in the Fz force in general, but it was observed that the tool flank wear and the inner surface quality of the nozzle were at acceptable levels. It is understood that the changes in the moment $(\mathrm{Mz})$ occur in a wider range as a result of the forces acting perpendicular to the tool's advance direction and increase depending on the number of holes. The average surface roughness $\mathrm{Ra}$ values obtained on the inner surfaces of the nozzles are $0.34 \mu \mathrm{m}$, and similarly, the success of the design and production experiment showed that it can be used for Euro7 nozzle production.

\section{Acknowledgment}

This study was supported by TUBITAK/TURKEY in frame of the project code of 3170550 as researchers, we thank the TUBITAK/TURKEY.

\section{Conflict of Interest Statement}

The authors declare that there is no conflict of interest in the study.

\section{CRediT Author Statement}

Hakan Küçüktürk: Investigation, Validation, Software, Writing-original draft,

Gökhan Küçüktürk: Visualization, Writing - review \& editing,

Şükran Katmer: Visualization, Writing - review \& editing,

Çağlar Yavaș: Investigation, Validation, Software,

Ulvi Şeker: Methodology, Supervision,

\section{References}

[1] Lee, S.M., et al., Friction drilling of austenitic stainless steel by uncoated and PVD AlCrN- and TiAlN-coated tungsten carbide tools. International Journal of Machine Tools and Manufacture, 2009. 49(1): p. 81-88.

[2] Chen, W.-C., et al., Design optimization of a split-point drill by force analysis. Journal of Materials Processing Technology, 1996. 58(2): $\mathrm{p}$. 314-322.

[3] Audy, J., A study of computer-assisted analysis of effects of drill geometry and surface coating on forces and power in drilling. Journal of Materials Processing Technology, 2008. 204(1): p. 130-138. 
[4] Audy, J., A Study of Computer Assisted Analysis of Effects of Drill Point Geomerical Features on Forces and Power in Drilling with general purpose twist drills. ECU Publications, 2008. 2008.

[5] Tsao, C.-C., Prediction of flank wear of different coated drills for JIS SUS 304 stainless steel using neural network. Journal of Materials Processing Technology, 2002. 123(3): p. 354-360.

[6] Kurt, M., E. Bagci, and Y. Kaynak, Application of Taguchi methods in the optimization of cutting parameters for surface finish and hole diameter accuracy in dry drilling processes. International Journal of Advanced Manufacturing Technology, 2009. 40: p. 458-469.

[7] Sambhav, K., S. Dhande, and P. Tandon, CAD Based Mechanistic Modeling of Forces for Generic Drill Point Geometry. ComputerAided Design and Applications, 2013. 7: p. 809-819.

[8] Wang, J. and Q. Zhang, A study of high-performance plane rake faced twist drills.: Part I: Geometrical analysis and experimental investigation. International Journal of Machine Tools and Manufacture, 2008. 48(11): p. 1276-1285.

[9] Gokce, H., M. Yavuz, and U. Şeker, Matkap Geometrisinin Oluşturulmasında Parametrik Modelleme Yaklaşımı. 2017.

[10]Bahçe E., K.E., Özel C., Al-5005'in delinmesinde delme parametrelerinin çapak oluşumuna etkisinin araştırılması, in 2. Ulusal Tasarım İmalat ve Analiz Kongresi. 2010: Balıkesir. p. 242 - 250.

[11]Yağmur, S., Acır, A., Şeker, U., and Günay, M., Delik Delme İşlemlerinde Kesme Parametrelerinin Kesme Bölgesindeki Sicaklığa Etkisinin Deneysel İncelenmesi. Journal of the Faculty of Engineering and Architecture of Gazi University., 2013. 28: p. 1-6.

[12]Uzun G., Y.S.A., Korkut İ., Ti-6Al-4V Alaşımının Delinmesinde Kesme Parametrelerinin Kesme Kuvvetlerine ve Delik Kalitesine Etkisinin İncelenmesi. Karaelmas Science and Engineering Journal., 2017. 7: p. 469-475.

[13]Lin, T.R., Cutting Behaviour Using Variable Feed and Variable Speed when Drilling Stainless Steel with TiN-Coated Carbide Drills. The International Journal of Advanced Manufacturing Technology, 2002. 19: p. 629-636.

[14]Balaji, M., B.S.N. Murthy, and N.M. Rao, Optimization of Cutting Parameters in Drilling of AISI 304 Stainless Steel Using Taguchi and ANOVA. Procedia Technology, 2016. 25: p. 1106-1113.

[15]Günay, M., Meral, T. Modelling and multiresponse optimization for minimizing burr height, thrust force and surface roughness in drilling of ferritic stainless steel. Sādhanā 45, $273 \quad$ (2020). https://doi.org/10.1007/s12046-020-01490-3

[16]Korkmaz ME, Meral T, Günay M. Drillability Analysis of AISI 420 Martensitic Stainless Steel by Finite Element Method. 2018 Dec 4;4:223-9.

[17]Chatterjee, S., et al., NSGA-II Approach of Optimization to Study the Effects of Drilling Parameters in AISI-304 Stainless Steel. Procedia Engineering, 2014. 97: p. 78-84.

[18]Y. Turgut, A.Ç., T. Kıvak, İ. Uygur, E. Ekici, Çok Katlı Kaplamaların AISI 304 Paslanmaz Çeliğin İşlenebilirliği Üzerindeki Etkileri, in 6th International Advanced Technologies Symposium. 2011: Elazı ğ, Turkey.

[19]Chen, W.-C. and X.-D. Liu, Study on the various coated twist drills for stainless steels drilling. Journal of Materials Processing Technology, 2000. 99(1): p. 226-230.

[20]Uysal, A., A Study on Drilling of AISI 304L Stainless Steel with
Nanocomposite-Coated Drill Tools. Arabian Journal for Science and Engineering, 2014. 39: p. 8279-8285.

[21]Ulaş Çaydaş, Ahmet Hasçalık, Ömer Buytoz \& Ahmet Meyveci (2011) Performance Evaluation of Different Twist Drills in Dry Drilling of AISI 304 Austenitic Stainless Steel, Materials and Manufacturing Processes, 26:8, 951-960.

[22]Nayan G Kaneriya, G.K.S., Experimental Evaluation and Optimization of Dry Drilling Parameters of AISI304 Austenitic Stainless Steel using Different Twist Drills, in 5th International \& 26th All India Manufacturing Technology, Design and Research Conference. 2014: Guwahati, Assam, India.

[23]Turgay KIVAK, K.H.v.U.Ş., Inconel 718'in delinmesinde kesme parametrelerinin yüzey pürüzlülüğü ve talaş oluşumu üzerindeki etkisinin araştırılması. Journal of the Faculty of Engineering and Architecture of Gazi University. 2010. 25: p. 293-298.

[24]Küçüktürk, H., Yudar, H. H., Meral, G., Şeker, U., Euro 7 Nozul Üretimi için Takımlandırma Tasarımı ve Performans Değerlendirmesi, in Uluslararası Talaşlı İmalat Semposyumu. 2019: Antalya Türkiye. p. 4. 